\title{
Adsorption of Copper, Zinc, and Nickel Using Loess as Adsorbents
}

\author{
Pongsakorn Punrattanasin ${ }^{1 *}$, Panha Sariem ${ }^{2 * *}$ \\ 'Research Center for Environmental and Hazardous Substance Management, Khon Kaen University \\ ${ }^{2}$ Department of Civil Engineering, Faculty of Engineering, Khon Kaen University, \\ 123 Moo 16 Mittapap Road, Nai-Muang, Muang District, Khon Kaen 40002, Thailand
}

Received: 30 June 2014

Accepted: 23 September 2014

\begin{abstract}
This study focuses on the investigation of the adsorption behavior of copper, zinc, and nickel on red and yellow loess by applying batch technique. Contact time, initial concentration of metal ions, and temperature were observed as the influential parameters in the adsorption process. The results expressed that the equilibrium time was attained within four hours; the adsorption capacity was temperature-dependent and endothermic. The removal efficiency at lower concentration was superior to the higher one, whereas the adsorption capacity was enhanced at higher concentrations. Freundlich and Langmuir models can be found satisfactory to predict the adsorption isotherm. The maximum adsorption capacities of red and yellow loess at $30^{\circ} \mathrm{C}$ of $\mathrm{Cu}, \mathrm{Zn}$, and $\mathrm{Ni}$ were respectively found to equal $0.95 \mathrm{mg} / \mathrm{g}, 1.27 \mathrm{mg} / \mathrm{g}, 0.79 \mathrm{mg} / \mathrm{g}, 1.23 \mathrm{mg} / \mathrm{g}, 1.65 \mathrm{mg} / \mathrm{g}$, and 1.65 $\mathrm{mg} / \mathrm{g}$. The yellow loess comprised with the highest removal capacities and the maximum adsorption capacities in comparison with the red one. Zinc consisted of the best adsorption affinity with the order of $\mathrm{Cu}<\mathrm{Ni}<\mathrm{Zn}$ for both kinds of adsorbents.
\end{abstract}

Keywords: adsorption, equilibrium, isotherm, removal, affinity

\section{Introduction}

The incredible progress of modern technology in recent years has been providing more facilities to human life. This advancement conversely has been enduring long-lasting consequences associated with the ecosystem and threats to human health, including discharge of waste effluents containing heavy metals by industrial activities such as metal plating, industry fertilizer, mining operations, metallurgy, manufacturing battery, and dyeing in textile industries [1]. Heavy metals are classified among the most hazardous environmental pollutants due to its inability disintegrate through physical processes [2]. This alarming issue is encouraging many researchers to devote their time to finding out the

\footnotetext{
*e-mail: ponpun@kku.ac.th

**e-mail: sariem.panha@yahoo.com
}

most efficient measures for the heavy metal removal purpose. Various removal methods such as filtration, chemical precipitation, ion exchange, adsorption using activated carbon, electrode-position, and membrane process have been initiated, but adsorption is considered one of the most efficient and inexpensive techniques to remove heavy metal ions from aqueous solution [3].

The study of adsorption process is utterly essential to comprehend how heavy metals are transferred from a liquid mobile phase to the surface of a solid phase [4]. Sarooj clay in United Arab Emirates, loess in China, clay in Tunisia, peat soil in Malaysia, and various kinds of soilds in northeastern Thailand have been selected to be adsorbents for adsorption studies, and reports show that those materials have a considerable affinity for heavy metals [5-9]. Red loess and yellow loess are widely discovered in northeastern Thailand, but their adsorption behavior remains unidentified. 
The objective of this study is to investigate the adsorption behavior of Copper $(\mathrm{Cu})$, Zinc $(\mathrm{Zn})$, and $\mathrm{Ni}$ (Nickel) on red loess and yellow loess found in northeastern Thailand in terms of the effects of contact time, initial concentration, and temperature.

\section{Materials}

\section{Adsorbents}

Loess can be defined as a terrestrial clastic sediment composed predominantly of silt-sized particles essentially formed by the accumulation of wind-blown dust [10]. Red loess and yellow loess in Khon Kaen province were designated as the adsorbents of this adsorption study. The soil samples were collected in various zones depending on loess presence, and dug at a depth of $50 \mathrm{~cm}$ from its surfaces. The samples were dried in the oven at $110^{\circ} \mathrm{C}$ for 24 hours for bulk water elimination purpose and sieved with a 100-mesh sieve. The basic and engineering properties of the adsorbents are shown in Table 1 .

\section{Adsorbates}

Copper $(\mathrm{Cu})$, Nickel (Ni), and Zinc (Zn) were selected in this research to represent the range of the common heavy metals and prepared in the form of the solution to be the adsorbates. The stock solutions of $\mathrm{Cu}\left(\mathrm{NO}_{3}\right)_{2}, \mathrm{Ni}\left(\mathrm{NO}_{3}\right)_{2}$, and $\mathrm{Zn}\left(\mathrm{NO}_{3}\right)_{2}$, at concentrations of $100 \mathrm{~g} / \mathrm{mL}$, were dissolved in the deionized water to obtain the preferred initial concentration of solution. The chosen initial concentration of the heavy metal solutions in this study were $5 \mathrm{mg} / \mathrm{L}, 100 \mathrm{mg} / \mathrm{L}$, $250 \mathrm{mg} / \mathrm{L}, 500 \mathrm{mg} / \mathrm{L}$, and $1000 \mathrm{mg} / \mathrm{L}$. The properties of heavy metal solutions are presented in Table 2 .

\section{Experimental Procedure}

\section{Characterization of Adsorbents}

The identification of the surface morphology of the adsorbents with different magnifications was determined by Scanning Electron Microscope (S-3000N, Hitachi, Japan). The chemical compositions of the adsorbents were examined X-Ray Fluorescence XRF. The specific area and the total pore volume were defined by ASAP-2010 according to Brunauer-Emmett-Teller (BET) adsorption theory. The natural $\mathrm{pH}$ of the adsorbents was measured by $\mathrm{pH}$ meter with proper calibration. The oven-dried and sieved soil samples with the mass of $10 \mathrm{~g}$ were placed into three different graduated beakers. $10 \mathrm{~mL}$ of deionized water was then poured into those containers. The mixtures were stirred for 1 minute using the plastic spoons and then left 1 hour before the $\mathrm{pH}$ measurement. The natural $\mathrm{pH}$ of the adsorbents was obtained by the average $\mathrm{pH}$ values of those three samples.
Table 1. Basic and engineering properties.

\begin{tabular}{|l|c|c|}
\hline \multicolumn{1}{|c|}{ Basic and Engineering Properties } & Yellow Loess & Red Loess \\
\hline \% Passing No. 200 sieve & 12.26 & 11.71 \\
\hline \% Passing No. 4 sieve & 93.18 & 96.45 \\
\hline Liquid Limit LL (\%) & 30.20 & 18.03 \\
\hline Plastic Limit PL (\%) & 20.60 & 13.00 \\
\hline Plasticity Index PI (\%) & 6.60 & 5.03 \\
\hline USCS Symbol & $\mathrm{SC}$ & $\mathrm{SM}$ \\
\hline Specific Gravity G & 2.63 & 2.68 \\
\hline Max. Dry Density $\left(\mathrm{g} / \mathrm{cm}^{3}\right)$ & 1.87 & 2.00 \\
\hline Coefficient of Permeability k $(\mathrm{cm} / \mathrm{s})$ & $2.27 \times 10^{-6}$ & $4.0 \times 10^{-6}$ \\
\hline
\end{tabular}

Table 2. Properties of heavy metal solutions.

\begin{tabular}{|l|c|c|c|}
\hline \multicolumn{1}{|c|}{ Properties } & $\begin{array}{c}\text { Copper } \\
\text { Nitrate }\end{array}$ & $\begin{array}{c}\text { Zinc } \\
\text { Nitrate }\end{array}$ & $\begin{array}{c}\text { Nickel } \\
\text { Nitrate }\end{array}$ \\
\hline Formula & $\mathrm{Cu}\left(\mathrm{NO}_{3}\right)_{2}$ & $\mathrm{Ni}\left(\mathrm{NO}_{3}\right)_{2}$ & $\mathrm{Zn}\left(\mathrm{NO}_{3}\right)_{2}$ \\
\hline Molecular weight $(\mathrm{g} / \mathrm{mol})$ & 241.60 & 290.80 & 297.50 \\
\hline Density $\left(\mathrm{g} / \mathrm{cm}^{3}\right)$ & 2.32 & 2.05 & 2.06 \\
\hline Solubility $(\mathrm{g} / 100 \mathrm{ml})$ & 137.80 & 94.20 & 184.30 \\
\hline
\end{tabular}

Table 3. Batch adsorption test scope.

\begin{tabular}{|l|c|}
\hline \multicolumn{1}{|c|}{ Parameters } & Description \\
\hline Mass of adsorbents $m(\mathrm{~g})$ & 2.00 \\
\hline Volume of adsorbate $V(\mathrm{~mL})$ & 50.00 \\
\hline $\mathrm{pH}$ & 6.70 \\
\hline Temperature $T\left({ }^{\circ} \mathrm{C}\right)$ & $30-40-50$ \\
\hline Contact time $t(\mathrm{~h})$ & $0.5-1-2-4-8-24$ \\
\hline Initial concentration $C_{0}(\mathrm{mg} / \mathrm{L})$ & $5-100-250-500-1000$ \\
\hline
\end{tabular}

\section{Batch Adsorption Test}

\section{General Procedure}

Batch techniques were performed to examine the adsorption behavior of $\mathrm{Cu}, \mathrm{Zn}$, and $\mathrm{Ni}$ using red and yellow loess as the adsorbents, including the effect of the contact time, the initial concentration of the solutes, and the effect of temperature. The contact time $t$ of the mixture ranged from $0.5 \mathrm{~h}$ to $24 \mathrm{~h}$. The initial concentrations $C_{0}$ of the aqueous solution were varied between $5 \mathrm{mg} / \mathrm{L}$ to $1000 \mathrm{mg} / \mathrm{L}$. The temperature conditions of the slurry solution during the adsorption process were $30^{\circ} \mathrm{C}, 40^{\circ} \mathrm{C}$, and $50^{\circ} \mathrm{C}$. The equilibrium time $t_{e}$ and equilibrium concentration $C_{e}$ were deter- 
mined in the case of the constancy of the remaining concentration $C_{t}$ while the contact time changed. Equilibrium time of batch adsorption test is the time interval in which the system reaches chemical equilibrium and the concentration of the products and reactants cease to change with the time respect [11]. The scope of this experiment is summarized in Table 3.

The selected dosage of the adsorbents in this study was $2 \mathrm{~g}$ while the volume of the aqueous solutions was $50 \mathrm{~mL}$. Each sample was stowed in a $60 \mathrm{ml}$ plastic bottle. The $\mathrm{pH}$ of the batch samples was set equal to the natural $\mathrm{pH}$ of the adsorbents. The diluted $\mathrm{NAOH}$ and $\mathrm{HCl}$ were added into the slurry solution to adjust their initial $\mathrm{pH}$. The initial $\mathrm{pH}$ of the adsorbates and the slurries were measured to determine the supplementary volume of reagents $(\mathrm{NaOH}$ and HCL). The designated $\mathrm{pH}$ of the batch samples was finally obtained by the addition of required NAOH and HCL. A pH-meter with proper calibration was regularly used to verify the $\mathrm{pH}$ of each adjustment. The shaking electric oven was then used to regulate the desired temperature condition during the adsorption process with the rotational speed of $130 \mathrm{rpm}$ in terms of the diverse contact times. The heavy metal solutions were then filtered through the millipore filters (pore size $0.45 \mu \mathrm{m}$ ) at the end of the contact times. The remaining concentration $C_{t}$ of the filtered solution was compulsorily lowered by the dilution process with $0.1 \%$ of nitric acid $\mathrm{HNO}_{3}$ conforming to the minimum detection limits of $\mathrm{Cu}$, $\mathrm{Ni}$, and $\mathrm{Zn}$, which were respectively $4 \mathrm{mg} / \mathrm{L}, 4 \mathrm{mg} / \mathrm{L}$, and 2 $\mathrm{mg} / \mathrm{L}$. A Perkin Elmer-200 atomic absorption spectrometer (Germany), functioning with an air acetylene flame, was used to measure the remaining concentration of the diluted solution. The calibration curve of each heavy metal was plotted based on its wavelength and standard solutions.

\section{Adsorption Isotherm}

Adsorption is the process in which atoms or molecules of a substance in one phase become bonded to the surface of a second substance in a different phase [12]. Adsorption isotherm predicts the amount of adsorbate adsorbed by an adsorbent in terms of the equilibrium concentration of the adsorbate at the constant temperature. Langmuir model and Freundlich model were selected to predict the adsorption isotherm of heavy metals on the Loess [13].

The percentage of heavy metal removal can be defined in Eq. (1):

$$
\text { Metal ion removal }(\%)=\left(C_{0}-C_{e}\right) \times \frac{100}{C_{0}}
$$

The adsorbed heavy metal amount $q_{e}(\mathrm{mg} / \mathrm{g})$ per unit adsorbent mass is shown by Eq. (2):

$$
q_{e}=\frac{\left(C_{0}-C_{e}\right) V}{m}
$$

...where $C_{0}$ is the initial heavy metal concentration, $C_{e}$ is the concentration of heavy metal at equilibrium $(\mathrm{mg} / \mathrm{L}), m$ is the mass of adsorbent (mg), and $V$ is the solution volume (L).
The Langmuir isotherm model assumes the existence of the homogeneous monolayer surface adsorption on which one ion per binding site was formed without side interactions between the adsorbed ions [14].

The expression of the Langmuir equation is indicated in Eq. (3):

$$
q_{e}=\frac{Q^{0} b C_{e}}{1+b C_{e}}
$$

...where $q_{e}$ is the mass ratio of the adsorbed solute on the adsorbent $(\mathrm{mg} / \mathrm{g}), C_{e}$ is the equilibrium solute concentration $(\mathrm{mg} / \mathrm{L}), Q^{0}$ is the maximum adsorption capacity of the adsorbent $(\mathrm{mg} / \mathrm{g})$, and $b$ is the Langmuir constant related to the binding site $(\mathrm{L} / \mathrm{mg})$.

The linear form of Eq. (32) can be rearranged in Eq. (4):

$$
\frac{C_{e}}{q_{e}}=\frac{1}{b Q^{0}}+\frac{C_{e}}{Q^{0}}
$$

In the plot of Eq. (3), $\frac{C_{e}}{q_{e}}$ yields a straight line with a slope $\frac{1}{Q}$ and intercept $\frac{1}{b Q}$.

The Freundlich isotherm model is one of the most common adsorption equations for a solid-liquid system to model the adsorption on heterogeneous surfaces and is defined in Eq. (5):

$$
q_{e}=K_{F} C_{e}^{1 / n}
$$

...where $K_{F}$ is the Freundlich constant representing the adsorption capacity and strength of the adsorptive bond, $n$ is the heterogeneity factor.

The linear form of Eq. (5) can be indicated in Eq. (6):

$$
\log q_{e}=\log K_{f}+\frac{1}{n} \log C_{e}
$$

In the plot of Eq. (6), $\log K_{f}$ is the intercept of the line when $C_{e}=1 \mathrm{mg} / \mathrm{L}, 1 / n$ is the gradient assuming a linear relationship. The value $n>1$ associates with the distribution of bonded ions on the sorbent surface, which points a constant partitioning of the sorption mechanism out, where the adsorbate penetrated the sorbent and represents good adsorption $[14,15]$.

\section{Results and Discussion}

\section{Characterization of Adsorbents}

The heterogeneities of the surfaces of red and yellow loess particles were observed via 5,000× magnification and were respectively shown in Figs. 1(a) and (b). It was indicated that the surface of the yellow loess particles was rougher than the red one. The basic parameters of adsorbent 
Table 4. Basic parameters of adsorbents.

\begin{tabular}{|l|c|c|}
\hline \multicolumn{1}{|c|}{ Parameters } & Yellow Loess & Red Loess \\
\hline Specific surface area $S_{B E T}\left(\mathrm{~m}^{2} / \mathrm{g}\right)$ & 18.84 & 8.00 \\
\hline Total pore volume $V_{T}\left(\mathrm{~cm}^{3} / \mathrm{g}\right)$ & 0.042 & 0.048 \\
\hline Mean pore diameter $D_{P}(\mathrm{~nm})$ & 9.07 & 24.40 \\
\hline Natural $\mathrm{pH} p H_{n a}$ & 6.58 & 6.70 \\
\hline
\end{tabular}

micro-structures and their natural $\mathrm{pH}$ are provided in Table 4. The plot of BET confirmed that the specific areas of Yellow and Red Loess were, respectively, $18.84 \mathrm{~m}^{2} / \mathrm{g}$ and $8.00 \mathrm{~m}^{2} / \mathrm{g}$. This can assume that the specific area of yellow loess was larger than the red one, which signifies that yellow loess was covered with more adsorption site.

According to XRF examination, the chemical compositions of the adsorbents were identified. It was seen that the content of silicate oxide $\mathrm{SiO}_{2}$, aluminum oxide $\mathrm{Al}_{2} \mathrm{O}_{3}$ and ferric oxide $\mathrm{Fe}_{2} \mathrm{O}_{3}$ were predominantly present in the total weight. This XRF pattern was marginally different from the red loess in China [16]. All the amounts of chemical compound of both adsorbents were approximately similar to each other except the presence of calcium oxide $\mathrm{CaO}$ in the red loess. Adsorbent chemical compositions are presented in Fig. 2.
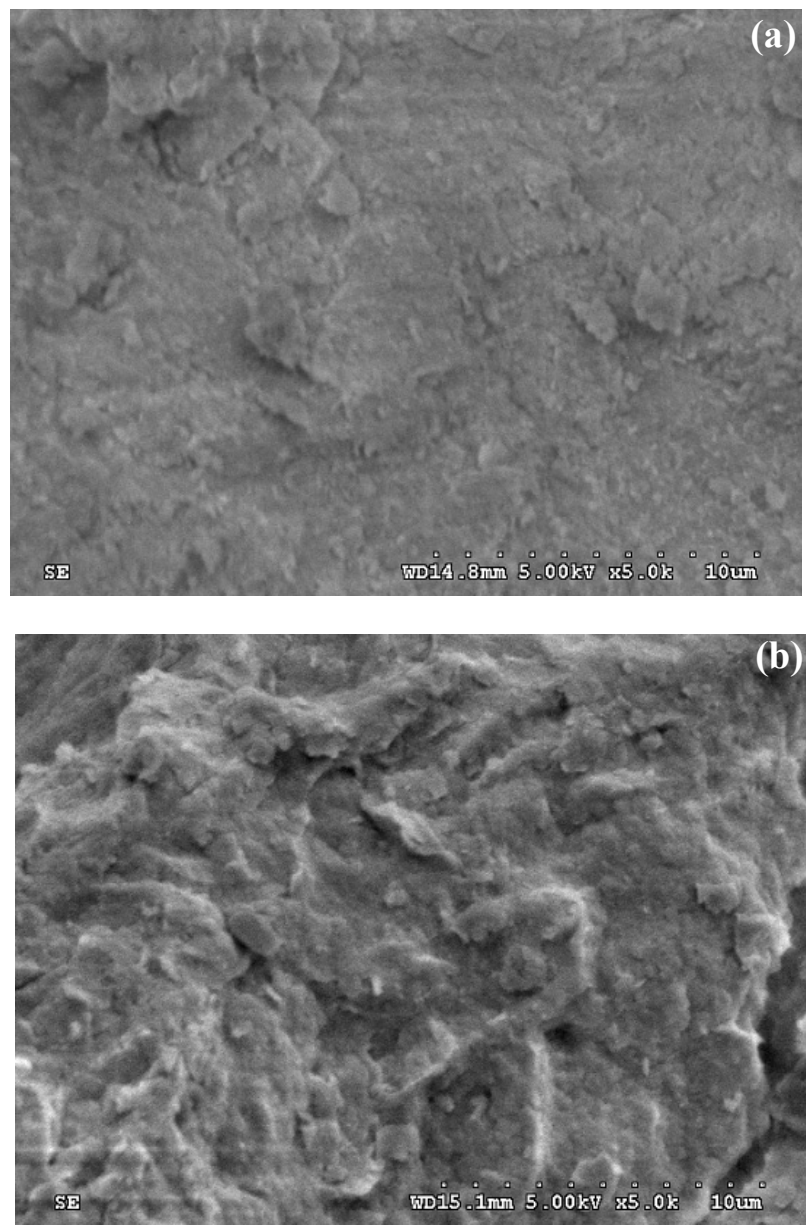

Fig. 1. 5,000x magnification of adsorbents.

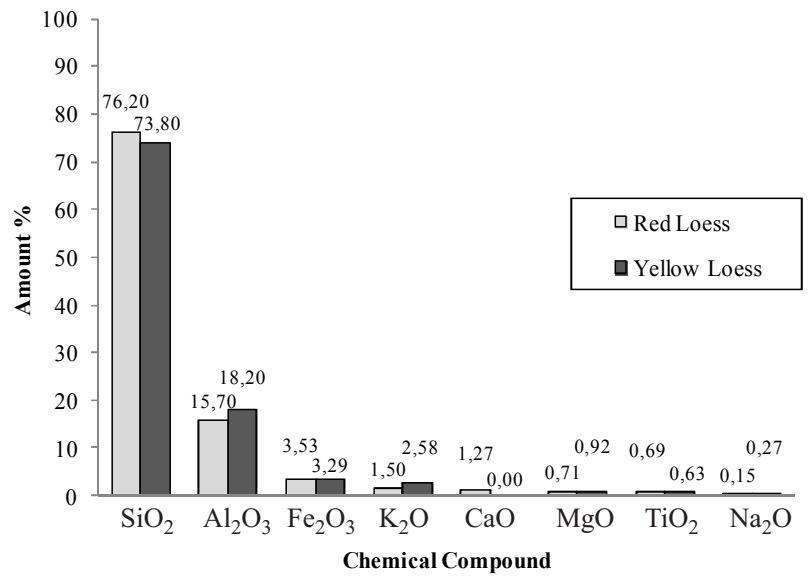

Fig. 2. Amount of adsorbent chemical compounds.

\section{Effect of Contact Time}

The gradual progression of the adsorption of $\mathrm{Cu}, \mathrm{Zn}$, and $\mathrm{Ni}$ on the red and yellow loess in terms of contact time is correspondingly depicted in Figs. 3 (a-c).

The removal percentage of heavy metal ions at the concentrations of $5 \mathrm{mg} / \mathrm{L}, 250 \mathrm{mg} / \mathrm{L}$, and $500 \mathrm{mg} / \mathrm{L}$ and as a function of contact time ranged from 0.5 hours to 24 hours was considered. The designated $\mathrm{pH}$ and the temperature of the slurry concentration were relatively 6.7 and $30^{\circ} \mathrm{C}$. It was seen that the percentage of removal of aqueous solutions at the concentration of $5 \mathrm{mg} / \mathrm{L}$ approximately attained up to $80 \%$ while the removal uptake achieved less than $20 \%$ in the case of other initial concentrations. The removal efficiency of the yellow loess appeared to be greater than the red one. This can be due to the larger surface area and adsorbing site. The adsorption process comprised with the intensive uptake at the beginning of the adsorption period and then was followed by the equilibrium state. The removal percentage showed a rising trend and then attained the stationary state around 4 hours. The phenomenon of the fast uptake at the beginning of the adsorption process was explained by the greater availability of the adsorbing site on the adsorbent surface at the preliminary period [17]. The uptake processes then became slower and steady when the surface adsorption site became saturated. This can be described by the slow transportation of heavy metal ions from the exterior to the interior sites of the soil particles or a very slow diffusion rate of the metal through the adsorbent micropores $[17,18]$.

\section{Effect of Initial Concentration}

The study of the adsorption of $\mathrm{Cu}, \mathrm{Zn}$, and $\mathrm{Ni}$ on the red and yellow loess in relation to the initial concentration of heavy metal ions variation was completed. A gap between the lowest and the highest initial concentrations was intentionally prepared in order to investigate the availability of removal efficiency of the adsorbents in terms of the concentration variation. The ongoing progression of the ion removal percentage $\% \mathrm{R}$ and the amount of uptake per unit 
mass of the adsorbents $Q_{e}(\mathrm{mg} / \mathrm{g})$ as a function of the initial concentration was demonstrated respectively in Figs. 4 (a) and (b).

Fig. 4 (a) illuminated that the removal rate at the concentration of $5 \mathrm{mg} / \mathrm{L}$ was up to $80.87 \%$ and then successively decreased with the lowest percentage of $2.59 \%$ at the concentration $1000 \mathrm{mg} / \mathrm{L}$. It can be assumed that the adsorption process of heavy metals showed high removal efficiency at the low initial metal ion concentration, whereas the descending removal rate occurred at the higher initial concentration. This may be attributed to the availability of

a)

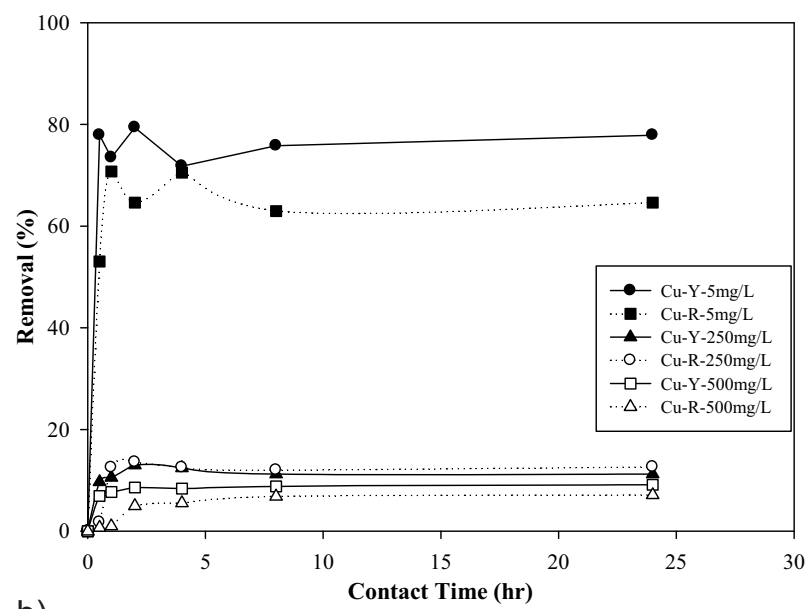

b)

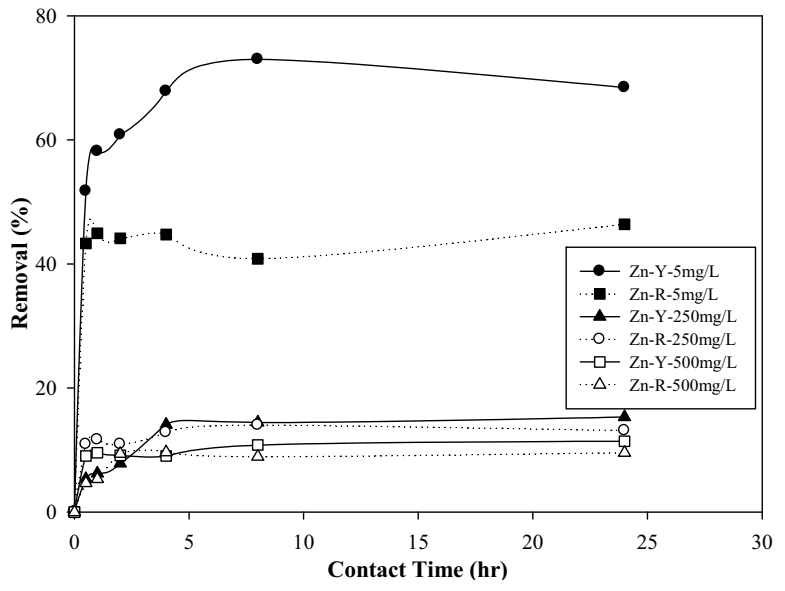

c)

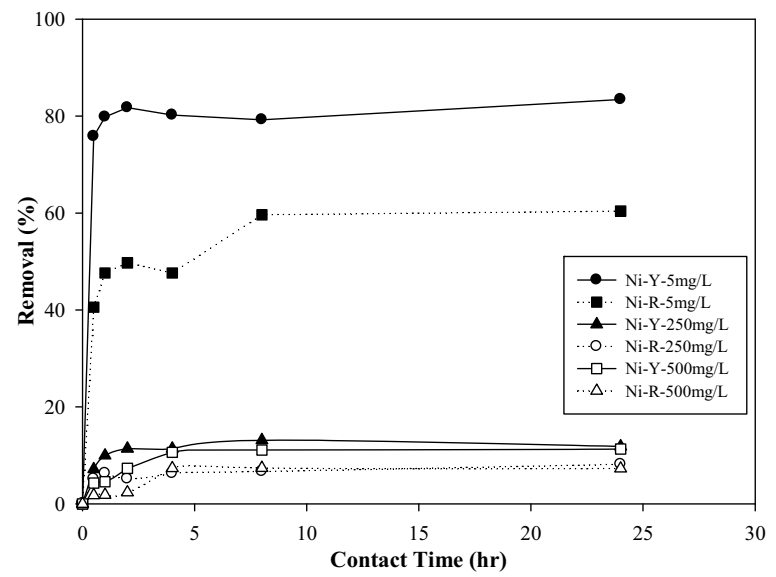

Fig. 3. Effect of contact time $\mathrm{pH}=6.7, \mathrm{~T}=30^{\circ} \mathrm{C}$
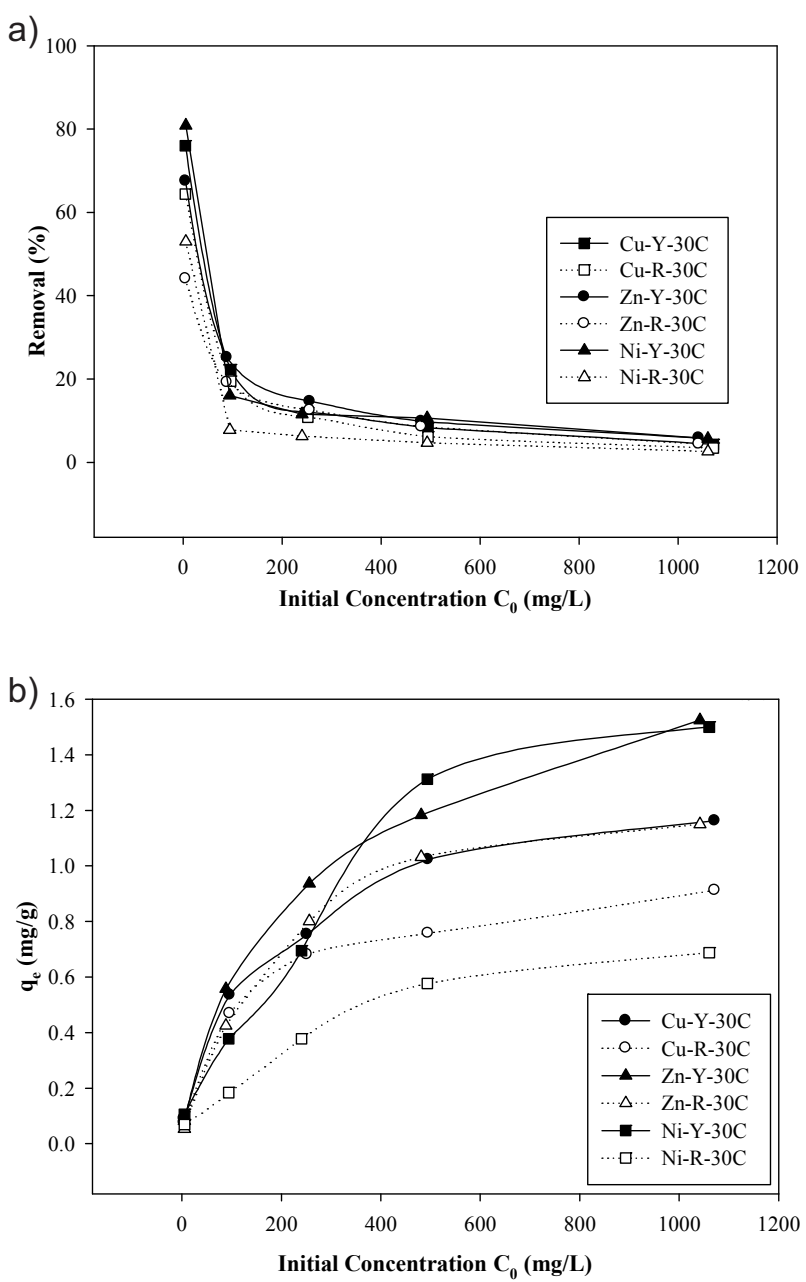

Fig. 4. Effect of initial concentration $\mathrm{pH}=6.7, \mathrm{~T}=30^{\circ} \mathrm{C}$.

the adequate adsorption site at the lower initial metal ion concentration and the insufficiency of the adsorbing site at the higher concentration due to the increase of the number of metal ions [19]. This trend was completely opposite to the adsorption capacity variation trend.

Fig. 4 (b) specified that the adsorption capacity at the initial concentration of $5 \mathrm{mg} / \mathrm{L}$ was approximately starting from $0.06 \mathrm{mg} / \mathrm{g}$. The adsorption capacity then showed a successive rising trend as the initial concentrations increased. The highest adsorption capacity at the initial concentration of $1000 \mathrm{mg} / \mathrm{L}$ was about $1.525 \mathrm{mg} / \mathrm{g}$ in the case of $\mathrm{Zn}-\mathrm{Y}-30^{\circ} \mathrm{C}$. This can assume that the adsorption capacity were higher at the greater initial concentration of heavy metal. This can be explained by the higher driving force for mass transfer with the increase in the initial concentration [3].

\section{Effect of Temperature}

The study of the temperature effect was performed conforming to the range of the temperature condition in Thailand. Figs. 5 (a-c) demonstrate the results of adsorption capacity $q_{e}(\mathrm{mg} / \mathrm{g})$ in terms of the equilibrium concentration $C_{e}(\mathrm{mg} / \mathrm{L})$ obtained from the application of Eq. 2 at the $30^{\circ} \mathrm{C}, 40^{\circ} \mathrm{C}$, and $50^{\circ} \mathrm{C}$. The gradual ascending trend of 
Table 5. Parameters of Freundlich and Langmuir models.

\begin{tabular}{|c|c|c|c|c|c|c|c|c|c|}
\hline \multirow{2}{*}{ Adsorbates } & \multirow{2}{*}{ Adsorbents } & \multirow{2}{*}{$\mathrm{T}\left({ }^{\circ} \mathrm{C}\right)$} & \multicolumn{3}{|c|}{ Freundlich Parameters } & \multicolumn{3}{|c|}{ Langmuir Parameters } & \multirow{2}{*}{$Q_{T}^{0}{ }_{T} Q_{30}^{0}$} \\
\hline & & & $K_{F}$ & $n$ & $\mathrm{R}^{2}$ & $b$ & $Q^{0}$ & $\mathrm{R}^{2}$ & \\
\hline \multirow{6}{*}{$\mathrm{Cu}$} & \multirow{3}{*}{ Yellow } & 30 & 0.091 & 2.58 & 0.992 & 0.012 & 1.23 & 0.987 & 1.00 \\
\hline & & 40 & 0.029 & 1.69 & 0.941 & 0.012 & 1.26 & 0.999 & 1.02 \\
\hline & & 50 & 0.110 & 2.56 & 0.988 & 0.013 & 1.50 & 0.986 & 1.22 \\
\hline & \multirow{3}{*}{ Red } & 30 & 0.069 & 2.51 & 0.976 & 0.014 & 0.95 & 0.991 & 1.00 \\
\hline & & 40 & 0.064 & 2.26 & 0.982 & 0.011 & 1.23 & 0.987 & 1.29 \\
\hline & & 50 & 0.082 & 2.40 & 0.992 & 0.010 & 1.32 & 0.984 & 1.45 \\
\hline \multirow{6}{*}{$\mathrm{Zn}$} & \multirow{3}{*}{ Yellow } & 30 & 0.071 & 2.16 & 0.993 & 0.009 & 1.65 & 0.978 & 1.00 \\
\hline & & 40 & 0.084 & 2.20 & 0.996 & 0.007 & 2.01 & 0.968 & 1.22 \\
\hline & & 50 & 0.076 & 1.95 & 0.981 & 0.010 & 2.21 & 0.985 & 1.34 \\
\hline & \multirow{3}{*}{ Red } & 30 & 0.035 & 1.83 & 0.976 & 0.009 & 1.27 & 0.994 & 1.00 \\
\hline & & 40 & 0.066 & 2.29 & 0.991 & 0.009 & 1.30 & 0.981 & 1.02 \\
\hline & & 50 & 0.043 & 1.81 & 0.980 & 0.009 & 1.63 & 0.984 & 1.28 \\
\hline \multirow{6}{*}{$\mathrm{Ni}$} & \multirow{3}{*}{ Yellow } & 30 & 0.095 & 2.56 & 0.958 & 0.009 & 1.65 & 0.978 & 1.00 \\
\hline & & 40 & 0.129 & 2.80 & 0.980 & 0.008 & 1.71 & 0.957 & 1.04 \\
\hline & & 50 & 0.200 & 3.13 & 0.987 & 0.011 & 1.93 & 0.979 & 1.17 \\
\hline & \multirow{3}{*}{ Red } & 30 & 0.044 & 2.56 & 0.960 & 0.006 & 0.79 & 0.945 & 1.00 \\
\hline & & 40 & 0.135 & 3.03 & 0.972 & 0.032 & 1.09 & 0.998 & 1.38 \\
\hline & & 50 & 0.129 & 2.79 & 0.980 & 0.022 & 1.38 & 0.995 & 1.67 \\
\hline
\end{tabular}

adsorbed heavy metal amount was found when the equilibrium concentration of the solution was augmented. The isotherm curves of each adsorbate-adsorbent variety at $40^{\circ} \mathrm{C}$ and $50^{\circ} \mathrm{C}$ were revealed to be superiorly positioned in comparison with those of $30^{\circ} \mathrm{C}$. This upgrading of adsorption efficiency at the greater temperature can make an assumption of the remarkable temperature influence in this adsorption study.

This can imply that this adsorption study is temperature-dependent and can be explicated by the expansion of the active surface sites of the adsorbents for the adsorption or the disolvation of the adsorbing species. The increase of temperature can reduce the thickness of the boundary layer surrounding the adsorbent so that the mass transfer resistance of adsorbates in the boundary layer diminished. It can be alternatively attributed to the acceleration of the diffusion rate of the solute within the pores of the adsorbent at higher temperature [19].

\section{Models of Adsorption Isotherm}

The analysis of isotherm feature has been commonly considered as the most effective approach to study the theoretical aspects of all adsorption processes [20]. The plots of adsorbed amounts of metal ions versus the equilibrium concentration of solute were called "Isotherm Curves" and illustrated in Figs. 5 (a-c). Three kinds of heavy metal $(\mathrm{Cu}-$ $\mathrm{Zn}-\mathrm{Ni}$ ), two types of adsorbents (red loess, yellow loess), and a range of temperature conditions $\left(30-50^{\circ} \mathrm{C}\right)$ as mentioned in Table 3 of the scope were the basic parameters to investigate the adsorption behavior in this study. The plotted curves, named the " $\mathrm{L}$ " isotherm curve, were presented according to the decrease of the ratio of the equilibrium concentration to the adsorbed on the solid when the solute concentration increased [21]. Freundlich and Langmuir models were applied to evaluate the adsorption behavior given by the application of Eqs. (4) and (6) in the form of linear curve.

Figs. 6 (a) and (b) exemplify separately the use of the Freundlich and Langmuir models to represent the adsorption performance of copper on the yellow loess at different temperatures. The adsorption parameters thus were calculated according to the equations of each trend line. The correlation coefficient $\mathrm{R}^{2}$ was the significant variable to verify their fitting trend. The results of this study are summarized in Table 5.

The adsorption intensity $n$ of Freundlich model was found within the range from 1.69 to 3.13 . This can certify that the adsorption of heavy metal ions on the red and yellow loess was a physical and good process [15]. Analysis by Langmuir model demonstrated that the comparison of the maximum adsorption capacity of unique adsorbent was 
in the order $\mathrm{Cu}<\mathrm{Ni}<\mathrm{Zn}$. It can be seen that $\mathrm{Zn}$ consisted of the highest sorption affinity and this was explained by the different affinities of metal ions for the donor atoms presented in the structure of the adsorbent [22]. It is eventually claimed that the adsorption efficiency of the yellow loess was greater than the red loess because of its larger surface area by comparing with the red loess. The ratios of the maximum adsorption capacity at $40^{\circ} \mathrm{C}$ and $50^{\circ} \mathrm{C}$ to the condition of $30^{\circ} \mathrm{C}$ were greater than the unity. Thus it can be concluded that temperature augmentation remarkably enhanced adsorption capacity. This result proved that the

a)
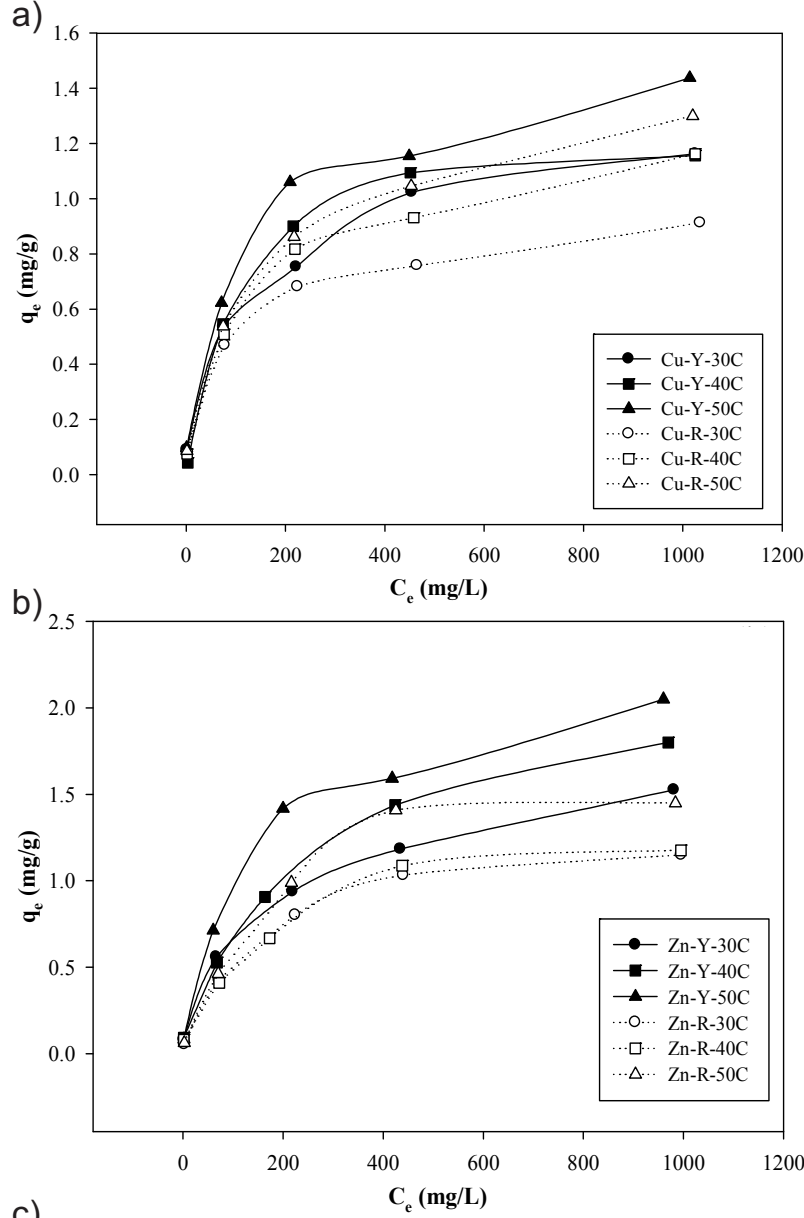

c)

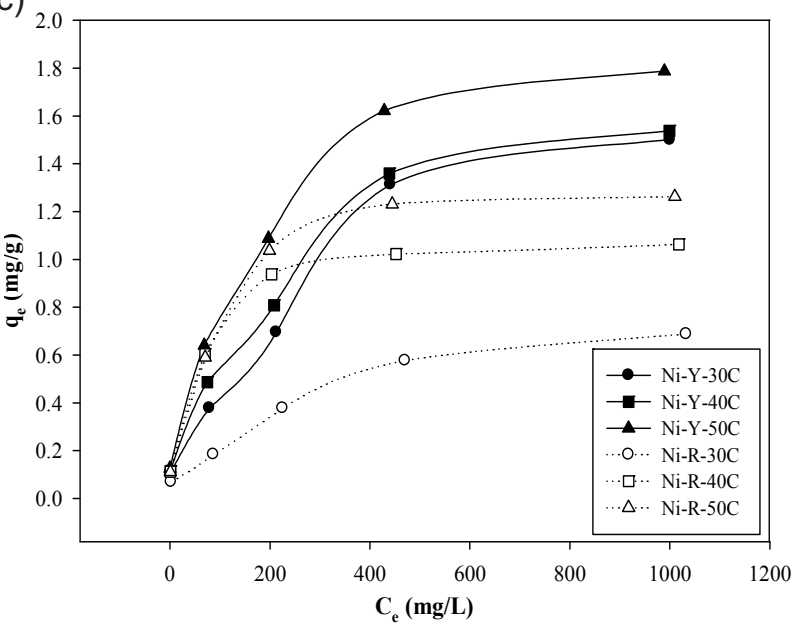

Fig. 5. Effect of temperature and isotherm curves $\mathrm{pH}=6.7$, $\mathrm{T}=30,40,50^{\circ} \mathrm{C}$.
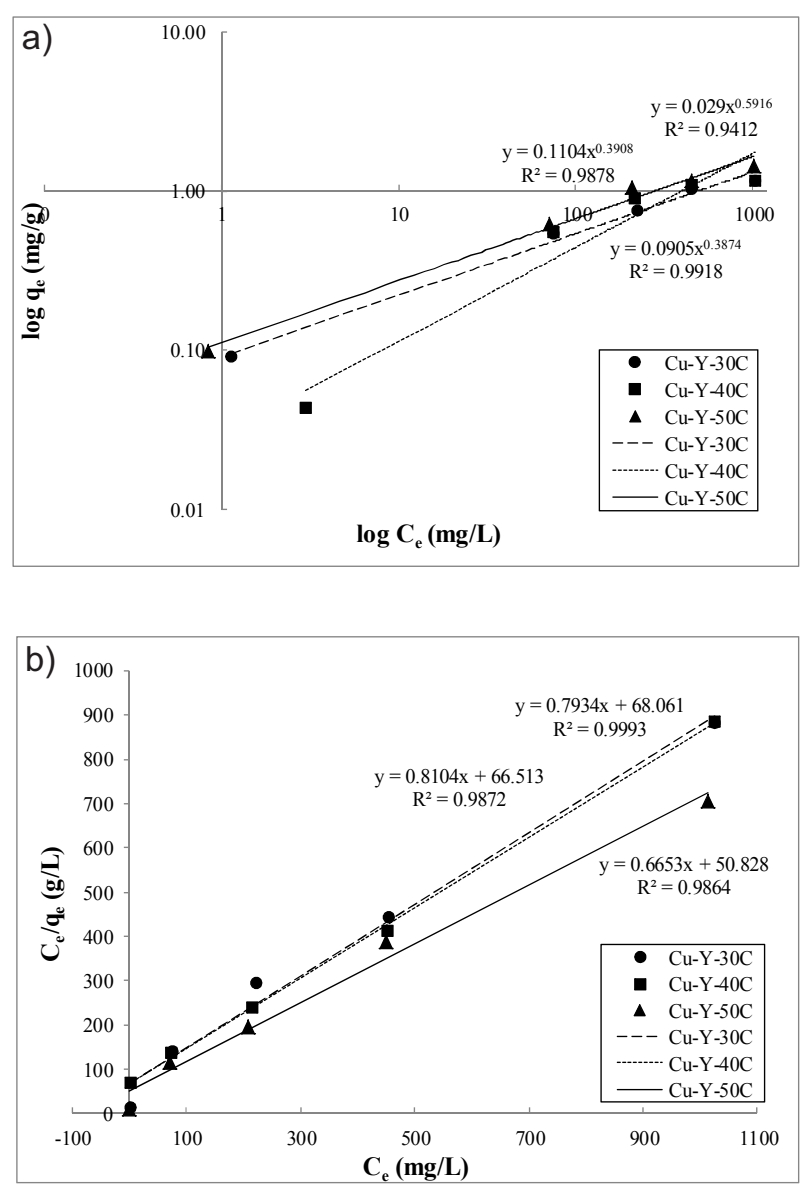

Fig. 6. (a) Freundlich Model (b) Langmuir Model of $\mathrm{Cu}-\mathrm{Y}$, $\mathrm{pH}=6.7, \mathrm{~T}=30,40,50^{\circ} \mathrm{C}$.

adsorption of $\mathrm{Cu}, \mathrm{Zn}$, and $\mathrm{Ni}$ was endothermic, which was compatible with the removal of heavy metal using red loess in China [16]. The correlation coefficient $\mathrm{R}^{2}$ of Freundlich and Langmuir models were respectively ranged from 0.941 to 0.996 and from 0.945 to 0.999 . This can imply that Freundlich and Langmuir models were appropriate to predict the adsorption behavior in this study.

\section{Conclusion}

The adsorption efficiency of $\mathrm{Cu}, \mathrm{Zn}$, and $\mathrm{Ni}$ on the red and yellow loess in Khon Kaen depended on the effect of the contact time, the initial concentration of heavy metal ions, and temperature. The equilibrium state was reached within four hours after the intensive uptake process at the initial stage of the adsorption. The removal efficiency at the lowest of the initial concentration $(5 \mathrm{mg} / \mathrm{L})$ was seen to be the highest amount, whereas the removal rate lessened progressively at the higher concentration (1000 mg/L). The adsorption capacities noticeably increased at the higher temperature condition. The maximum uptake capacities of yellow loess were better than those of the red loess due to its higher surface active site, while the adsorption capacity followed the order of $\mathrm{Cu}<\mathrm{Ni}<\mathrm{Zn}$. The isothermal data in this study can be modeled by Freundlich and Langmuir 
models and found fitting well. Loess showed a remarkable adsorption capacity. These raw and abundant materials, however, can illuminate greater adsorption capability if they can be modified and treated to improve their adsorption efficiency before using them for heavy metal removal.

\section{Acknowledgements}

The authors are grateful to Mr. Noppadol Sangiumsak for his precious collaboration and to the Faculty of Dentistry of Khon Kaen University for SEM examination. This research was funded by the Research Center for Environmental and Hazardous Substance Management and the Sustainable Infrastructure, Research, and Development Center (SIRDC), Faculty of Engineering, Khon Kaen University.

\section{References}

1. SRIVASTAVA V.C., MALL I.D., MISHA I.M. Characterisation of mesoporous rice husk ash (RHA) and adsorption kinetics of metal ions from aqueous solution onto RHA. J. Hazard. Mater. 134, (1-3), 257, 2006.

2. KASASSI A., RAKIMBEI P., KARAGIANNIDIS A., ZABANIOTOU A., TSIOUVARAS K., NASTIS A., TZAFEIROPOULOU K. Soil contamination by heavy metals: Measurements from a closed unlined landfill. Bioresour. Technol. 99, (18), 8578, 2008.

3. AYDIN H., BULUT Y., YERLIKAYA Ç. Removal of copper (II) from aqueous solution by adsorption onto low-cost adsorbents. J. Environ. Manage. 87, (1), 37, 2008.

4. BRADL H.B. Adsorption of heavy metal ions on soils and soils constituents. J. Colloid Interface Sci. 277, (1), 2004.

5. ABU-EISHAH S.I. Removal of $\mathrm{Zn}, \mathrm{Cd}$, and $\mathrm{Pb}$ ions from water by Sarooj clay. Appl. Clay Sci. 42, (1-2), 201, 2008.

6. ELOUSSAIEF M., JARRAYA I., BENZINA M. Adsorption of copper ions on two clays from Tunisia: $\mathrm{pH}$ and temperature effects. Appl. Clay Sci. 46, (4), 409, 2009.

7. WANG Y., TANG X., CHEN Y., ZHAN L., LI Z., TANG Q. Adsorption behavior and mechanism of $\mathrm{Cd}(\mathrm{II})$ on loess soil from China. J. Hazard. Mater. 172, (1), 30, 2009.
8. ABAT M., MCLAUGHLIN J.M., K.KIRBY J., STACEY P.S. Adsorption and desorption of copper and zinc in tropical peat soils of Sarawak, Malaysia. Geoderma. 175-176, 58, 2012.

9. SANGIUMSAK N., PUNRATTANASIN P. Adsorption Behavior of Heavy Metals on Various Soils. Pol. J. Environ. Stud. 23, (3), 853, 2014.

10. PYE K. The nature, origin and accumulation of loess. Quat. Sci. Rev. 14, (7-8), 653, 1995.

11. SUNA ERSES A., FAZAL M.A., ONAY T.T., CRAIG W.H. Determination of solid waste sorption capacity for selected heavy metals in landfills. J. Hazard. Mater. 121, (1-3), 223, 2005.

12. STOLTENBERG J., PENGRA D., VILCHES O. Physical Adsorption of Argon and Nitrogen on Graphite. 2012.

13. L.BOHN H., MCNEAL L.B., O'CONNOR G.A. Soil Chemistry, John Wiley \& Sons: New York. 1979.

14. JAVAID A., BAJWA R., SHAFIQUE U., ANWAR J. Removal of heavy metals by adsorption on Pleurotus ostreatus. Biomass Bioener. 35, (5), 1675, 2011.

15. DESTA M.B. Batch Sorption Experiments: Langmuir and Freundlich Isotherm Studies for the Adsorption of Textile Metal Ions onto Teff Straw (Eragrostis tef) Agricultural Waste. J. Thermodyn. 2013, 6, 2013.

16. XING S., ZHAO M., MA Z. Removal of heavy metal ions from aqueous solution using red loess as an adsorbent. J. Environ. Sci. 23, (9), 1497, 2011.

17. PEHLIVAN E., ARSLAN G. Removal of metal ions using lignite in aqueous solution - Low cost biosorbents. Fuel Process. Technol. 88, (1), 99, 2007.

18. MARKIEWICZ-PATKOWSKA J., HURSTHOUSE A., PRZYBYLA-KIJ H. The interaction of heavy metals with urban soils: sorption behaviour of $\mathrm{Cd}, \mathrm{Cu}, \mathrm{Cr}, \mathrm{Pb}$ and $\mathrm{Zn}$ with a typical mixed brownfield deposit. Environ. Int. 31, (4), 513, 2005.

19. MEENA A.K., MISHRA G.K., RAI P.K., RAJAGOPAL C., NAGAR P.N. Removal of heavy metal ions from aqueous solutions using carbon aerogel as an adsorbent. J. Hazard. Mater. 122, (1-2), 161, 2005.

20. GHORBEL-ABID I., TRABELSI-AYADI M. Competitive adsorption of heavy metals on local landfill clay. Arabian J. Chem. 2011.

21. GILES C.H., SMITH D., HUITSON A. A general treatment and classification of the solute adsorption isotherm. I. Theoretical. J. Colloid Interface Sci. 47, (3), 755, 1974.

22. BULUT Y., TEZ Z. Removal of heavy metals from aqueous solution by sawdust adsorption. J. Environ. Sci. 19, (2), 160, 2007. 